\title{
STRUCTURAL EVOLUTION AND EXHUMATION HISTORY OF THE RHODOPE UHP-HP METAMORPHIC PROVINCE (NORTHERN GREECE)
}

\author{
A. $\mathrm{KROHE}^{1} \&$ E. MPOSKOS ${ }^{2}$
}

\section{ABSTRACT}

Middle/Early Alpine UHP-HP domain of the Rhodope (N'Greece) show pressures $>3.6 \mathrm{Gpa}$. UHP-HP rocks have been emplaced in three major tectonic pulses: (i) At about 65->48 Ma the UHP Kimi Complex was exhumed at the surface representing the structurally uppermost UHP unit. (ii) Between $>42-30 \mathrm{Ma}$, the Sidironero, Kardamos and Kechros Complexes were exhumed underlying the Kimi Complex in the central and eastern Rhodope, respectively. They are characterized by HP-metamorphism (some parts by UHP-metamorphism), isothermal decompression and probably rapid exhumation. Exhumation tectonics involves deep level thrusting, synchronous high level extension, and successive post-thrusting extension. The post-thrusting Xanthi low angle normal detachment system extending over a distance of $100 \mathrm{~km}$, from central Rhodope to eastern Rhodope, is interpreted to be responsible for a decrease in recent crustal thickness of about $20 \mathrm{~km}$ from central to eastern Rhodope. Lutetian (c. 48-43Ma) to Oligocene marine basins transgressed atop the Kimi Complex representing the upper plate of all detachment generations. (iii) The third exhumation pulse between 26 to 8 $\mathrm{Ma}$, exhumed the Thasos/Pangeon metamorphic core complexes representing the structurally lowermost tectonic units of the Rhodope domain. Their exhumation occurred by displacements on the Miocene Strymon and Thasos detachment systems.

KEY WORDS: Tertiary, exhumation, UHP-HP metamorphic rocks, structural geology, Rhodope Zone

\section{INTRODUCTION}

The ultra high- and high pressure (UHP-HP) province of the Rhodope Domain (Greek-Bulgarian boundary region) consists of Variscan continental crust, Mesozoic metasediments and remnants of oceanic crust. The tectonometamorphic record reflects an early Alpine oceanic and continental subduction/accretion, crustal thickening and extension followed by Late Alpine back arc extension (Kilias et al., 1987, Mposkos, 1989, Dinter, 1998, Burg et al., 1996, Mposkos and Krohe, 2000). Alpine UHP metamorphism reaches more than of $3.6 \mathrm{GPa}$ at $800^{\circ} \mathrm{C}$ indicated by inclusions of diamonds and coesite pseudomorphs in garnet (Mposkos et al., 2001)

We introduce a new structural subdivision of the Greek "Rhodope Domain"; (cf. Mposkos and Krohe, 2000 for denotation; Fig.1). Based on new structural data, and on petrological and geochronological data (Fig. 1) we present a kinematic model of the alpine crustal movements of the Rhodope Domain.

\section{NEW TECTONIC SUBDIVISION-OVERVIEW}

In the east, the UHP-HP province is overlain by a thin lid of supracrustal rocks of the corresponding to the E' Circum Rhodope Zone; (E' CRZ; Fig.1). This lid consists of ophiolitic sequences that stayed close to the surface since the Jurassic, indicated by K-Ar hornblende ages and apatite fission track ages both ranging at about $150 \mathrm{Ma}$ (review in Hatzipanagiotou et al.; 1994; Bigazzi et al., 1989). Associated with the ophiolites are weakly metamorphosed phyllites and marbles at temperatures not exceeding c. $400^{\circ}$ (chlorite zone).

The UHP-HP province of the Rhodope Domain underneath this lid is itself a composite terrain of superimposed tectonic metamorphic complexes. These are separated from each other by large scale discrete low-angle extensional detachment systems formed during several consecutive events (Mposkos and Krohe, 2000). Generally, geochronological ages decrease downward and suggest -roughly- three major episodes of successive exhumation/cooling of structurally deeper sections.

1. University of Muenster, Institute for Mineralogy, Laboratory for Geochronology, Corrensstrasse 24, D-48149 Muenster (Germany), e-mail: krohe@uni-muenster.de

2. National Technical University of Athens, Section of Geological Sciences, 9 Heroon Politechniou Str., GR-15780, Zografou, Greece, e-mail: mposkos@metal.ntua.gr 


\section{KIMI-, KOTILI-MELIVIA- AND VERTISKOS COMPLEXES}

The uppermost tectonic complexes of the Rhodope Domain are the Kimi-, Kotili-Melivia- and the Vertiskos Complexes (Fig. 1) in eastern, central and western Rhodope respectively. These consist of high-pressure hightemperature $(\mathrm{HP} / H T)$ sequences of migmatitic gneisses and intercalated marbles that host boudins of eclogiteamphibolites and metaperidotites. Cretaceous ( $>80 \mathrm{Ma}) \mathrm{K}$-Ar mica cooling ages of the Vertiskos Complex and transgressive Eocene conglomerates on the Kimi Complex (Fig.1) indicate that these complexes were exhumed before the Eocene.

The metamorphic history of the Kimi Complex is representative for the uppermost high-grade metamorphic complexes. UHP metamorphism is locally recorded by inclusions of diamond and coesite pseudomorphs in garnet. Boudins of spinel-garnet pyroxenites, (Grt-Cpx $\pm \mathrm{Sp} \pm \mathrm{Ol}-\mathrm{Hbl}$; abbreviations after Bucher and Frey, 1994), garnet-peridotites (Grt-Cpx-Opx-Ol-Spl) and eclogites (Grt-Cpx-Qtz-Rt) record HP metamorphism at $15.5 \mathrm{kbar}$ and $770 \pm 40{ }^{\circ} \mathrm{C}$ probably after exhumation of these rocks from the UHP-stage. This is inferred by Grt-Cpx geothermometry in eclogites and from the equilibrium conditions of the reaction $\mathrm{Cpx}+\mathrm{Opx}+\mathrm{Spl} @ \mathrm{Brt}+\mathrm{Ol}$ (Mposkos and Krohe, 2000). A successive amphibolite facies metamorphism is associated with formation of muscovite-pegmatites and migmatites in the gneisses at about 10 kbar. A Sm-Nd garnet-clinopyroxene-whole rock age from a garnet-spinel-pyroxenite yielded c. $119 \mathrm{Ma}$ (Wawrzenitz and Mposkos, 1997). A Rb-Sr mica age of $65 \mathrm{Ma}$ from a pegmatite formed during the amphibolite facies stage is interpreted as crystallization age (Mposkos and Wawrzenitz, 1995).

\section{KERDILION, SIDIRONERO, KARDAMOS AND KECHROS COMPLEXES}

The Vertiscos, Kotili-Melivia and Kimi Complexes are underlain by the Kerdilion (W' Rhodope), Sidironero, Kardamos (central Rhodope), and Kechros (E' Rhodope; Fig.1) Complexes. These complexes consist of paraand orthogneisses (locally migmatitic), marbles, amphibolites, eclogites and sparse ultramafic rocks that underwent variable degrees of metamorphism. Various $\mathrm{K}$-Ar and $\mathrm{Rb}-\mathrm{Sr}$ mineral ages ( $45-32 \mathrm{Ma}$ ) indicate Early Tertiary exhumation.

The Sidironero Complex is a composite tectonic complex characterized by downwardly decreasing pressures and temperatures during (U)HP metamorphism and successive decompression stages. The structurally higher part mainly consists of orthogneisses and pelitic gneisses transformed to banded migmatites, containing elongated boudins of amphibolitized eclogites. Locally, diamonds and polycrystalline quartz aggregates pseudomorphing after coesite occur as inclusions in garnets of metapelites and amphibolitized eclogites respectively (Mposkos et al., 2001) indicating minimum pressures of $>36 \mathrm{Kbar}$ for an assumed minimum $\mathrm{T}$ of $800^{\circ} \mathrm{C}$. A kyanite eclogite from the Thermes area (Fig.1) indicates minimum pressures of c. $19 \mathrm{kbar}$ and at least $700^{\circ} \mathrm{C}$ (Liati and Seidel (1996). Migmatites formed within the stability fields of kyanite $+\mathrm{K}$-feldspar and sillimanite $+\mathrm{K}-$ feldspar (Mposkos and Liati, 1993) suggesting a stage of near isothermal decompression. Successive cooling into the stability field of Ms+Qtz occurred below $6 \mathrm{kbar}$ as is indicated by the low Si content of the magmatic muscovites $(\mathrm{Si}=6.2)$ from migmatitic pegmatites. Decompression was accompanied by strong pervasive plastic deformation followed by static annealing. SHRIMP-zircon data from a (partly amphibolized) eclogite and migmatites are 40 and $42 \mathrm{Ma}$ respectively (Liati and Gebauer; 1999). These reflect a minimum age of high-P metamorphism and exhumation of the Sidironero Complex.

The lowermost part of the Sidironero Complex consisting of the Falakron (largely marble) and the Albite Gneiss Series (Fig.1) is characterized by low grade metamorphism. Maximum temperatures did not exceed the stability field of the mineral assemblage $\mathrm{Grt}+\mathrm{Cld}+\mathrm{Chl}$ in metapelites. The maximum phengite component ( $\mathrm{Si}=7.11$ in albite gneisses) and the calculated reaction curve $\mathrm{Cld}+\mathrm{Chl}+\mathrm{Qtz} \rightarrow \mathrm{Grt}$ (rim) $+\mathrm{H} 2 \mathrm{O}$ (using Grt and Cld compositions from metapelites) indicate an equilibration stage at $12 \mathrm{kbar}$ at $490^{\circ} \mathrm{C}$ (Mposkos and Krohe, 2000).

Decompression occurred with slightly increasing temperature. This is suggested by prograde compositional zoning in hornblende from amphibolite, from tremolitic in the core to tschermakitic hornblende in the rim (Mposkos and Krohe, 2000). Orthogneisses, metapelites and amphibolites are mylonitic. Phengitic white mica flakes are generally pre-mylonitic clasts. Recrystallized white-mica have a lower Si-content confirming deformation during decompression (at pressures of 5-6 kbar; Mposkos and Krohe, 2000).

The Kardamos Complex is also a composite tectonic complex showing downwardly decreasing temperatures. The structurally higher high grade part of the Kardamos Complex includes a broad migmatitic/magmatic zone. The mineral assemblages $\mathrm{Grt}+\mathrm{St}+\mathrm{Bi}$ and $\mathrm{St}+\mathrm{Bi}+\mathrm{Sil}$ formed in metapelites during decompression infer minimum temperatures of $\sim 640^{\circ} \mathrm{C}$ (Bucher and Fey, 1994). At this stage, the marginal parts of this zone were strongly 


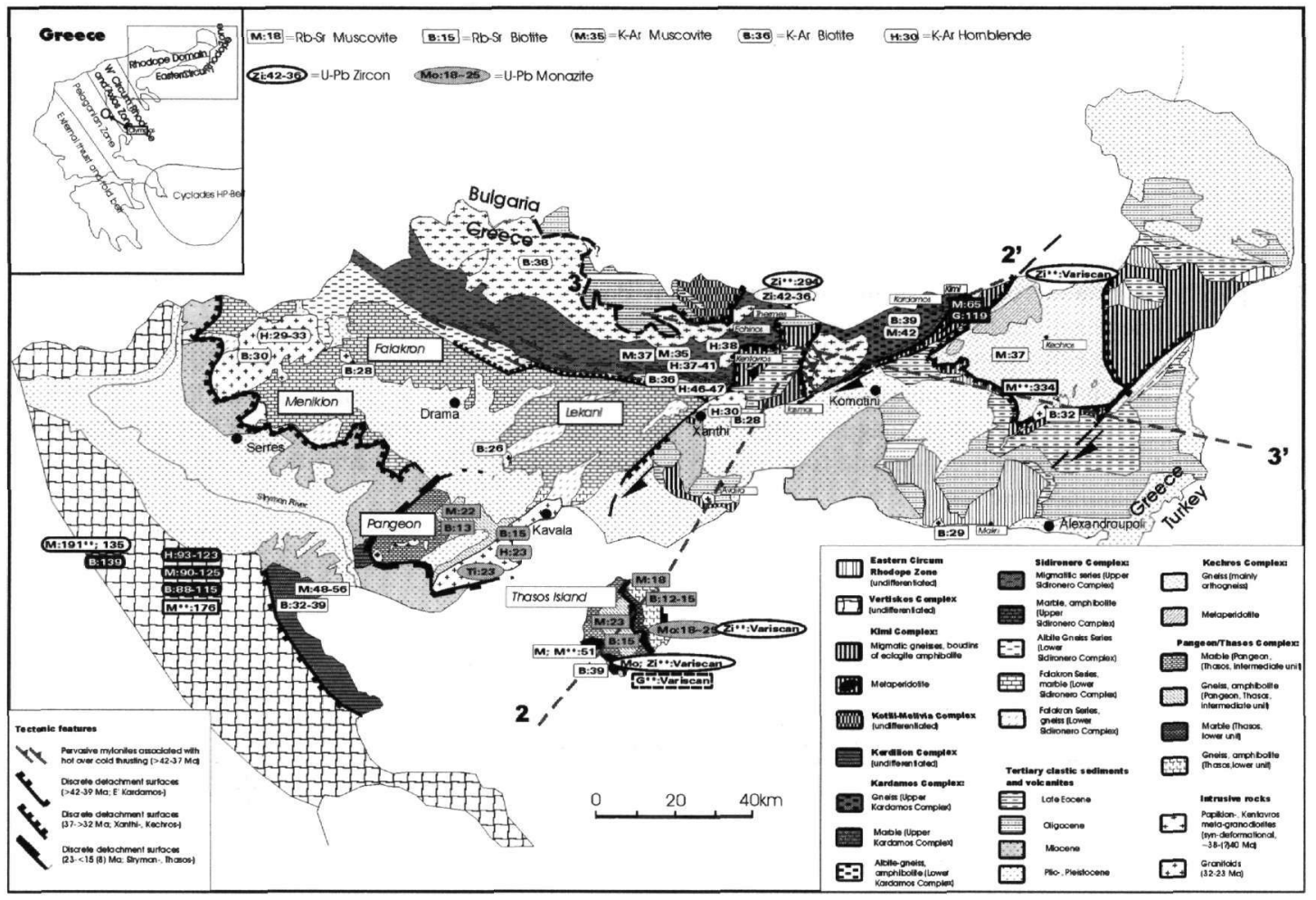

Figure 1: Structural subdivision of the Rhodope Domain and location of major detachment systems.

mylonitized.

The structurally lower low grade part, of the Kardamos Complex consists of albite gneisses, metabasites and intercalated marbles. In orthogneisses and layered paragneisses the relict HP mineral assemblage Grt-Ky-Zo$\mathrm{Pl}(\mathrm{An} 19-25)$-Qtz indicates 13-15 kbar for an assumed temperature of $600^{\circ} \mathrm{C}$ (Grt-Pl geobarometry). Decompression produced the mineral assemblages Grt-Ms-Bi-Ab-Olg \pm Kfs-Qtz in pelitic gneisses and Grt-Hbl-BiCzo-Ab-Olg-Qtz in metabasites. Staurolite coexisting with chlorite replaced garnet or kyanite. This limits the peak temperature above $550^{\circ} \mathrm{C}$ and below $620^{\circ} \mathrm{C}$ (Bucher and Frey, 1994) suggesting that decompression was nearly isothermal but at lower temperatures than in the structurally higher part of the Kardamos Complex. During decompression rocks were pervasively mylonitized.

The Kechros Complex consists of low- to medium-grade orthogneisses, pelitic gneisses containing elongated boudins of eclogites, and ultramafics. No $\mathrm{H} T / \mathrm{H} P$ series are present. Eclogites [Grt $+\mathrm{Omp}\left(\mathrm{Jd}_{35.55}\right) \pm \mathrm{Ky}+\mathrm{Tr}+$ $\mathrm{Hbl}+\mathrm{Czo}+\mathrm{Qtz}+\mathrm{Rt} \pm \mathrm{Phen}]$ indicate minimum pressure of $15 \mathrm{kbar}$ at c. $550^{\circ} \mathrm{C}$ (Mposkos and Perdikatsis, 1989, Liati and Mposkos, 1990). In gneisses, the maximum phengite component of white micas is $\mathrm{Si}=7$ atoms p.f.u (Mposkos, 1989). Near isothermal decompression (to about 4 kbar) is indicated by staurolite formation by chloritoid consuming reactions (e.g. $\mathrm{Cld}+\mathrm{Ky} \rightarrow \mathrm{St}+\mathrm{Chl}$ and $\mathrm{Cld}+\mathrm{Chl} \rightarrow \mathrm{St}+\mathrm{Bi}$ (Mposkos, 1989; Mposkos and Liati, 1993). Thick mylonite zones were created during decompression. In the uppermost Kechros Complex localized shearing continued through cooling to the lower greenschist facies.

\section{THASOS/PANGEON METAMORPHIC CORE COMPLEXES}

The lowermost tectonic units belong to the Thasos/Pangeon Metamorphic Core Complex in W' Rhodope. It consists of low to medium grade orthogneisses, metapelites, marble complexes as well as mafic rocks (Fig. 1). In Pangeon Mountains phengitic white micas ( $\mathrm{Si}=6.8$ atoms p.f.u; Mposkos and Krohe, 2000) occurring as relicts in mylonitized orthogneisses indicate an earlier high- $P$ metamorphism. Mylonitization occurred during decompression as it is indicated by the lower phengite component of the recystallized white mica. On Thasos Island, the metamorphic grade downwardly increases (Wawrzenitz and Krohe, 1998). 


\section{DEFORMATION DURING DECOMPRESSION (CENTRAL AND EASTERN RHODOPE)}

\section{Pervasive mylonite zones}

In upper and lower part of the Sidironero Complex, foliation planes moderately dip to the NE and bear NE plunging lineations. Shear sense criteria consistently document top to the SW (updip) movements in accordance with thrusting of the hot upper part of the Sidironero Complex over cold lower part cf. Dinter et al., 1995, and references therein; "Nestos thrust" zone).

Mylonites of the Kardamos Complex show inhomogeneous directions of shear. In the uppermost Kardamos Complex the mylonitic foliation forms a moderately NW dipping antiform, with the migmatitic/magmatic zone in the core. The plunge of lineations fluctuates around the antiform from SSW and S in the southern limb to SE and ENE in the northern limb of the antiform. Shear senses indicate top to the S-, SE- and ENE-movements in the respective zones. Thus, generally, a component of normal faulting is indicated. In the lower Kardamos Complex, beneath the migmatitic/magmatic zone the dip of the mylonitic foliation and the plunge of the lineation is to the NE. Shear senses indicate top to the SW movements, in accordance with SW thrusting of hotter above cooler metamorphic rocks.
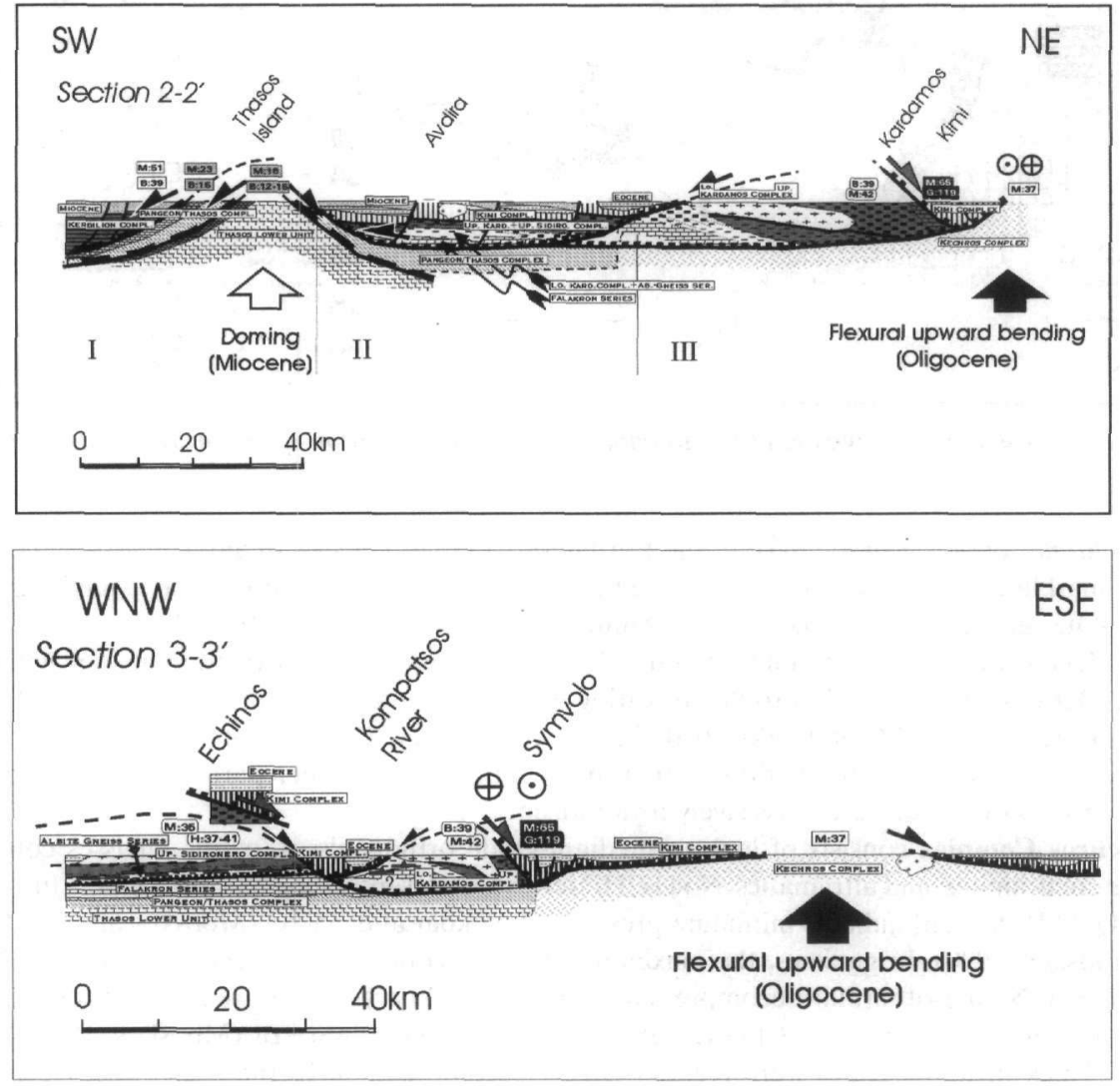

Figure 2: Profile through the Rhodope domain. Vertical scale is two times horizontal scale. See Fig. 1 for location of profiles, and for unit fillings.

In the Kechros Complex, the foliation planes of the thick mylonites and the localized shear zones trend NE to NW, dip shallowly to the $\sim \mathrm{N}$ and bear $\mathrm{N}$ to NE plunging lineations. Shear sense criteria generally indicate top to the S and SSW shearing. These mylonites may be linked to compression and extension.

\section{Discrete Tectonic Contacts (Detachment Surfaces)}

The following detachment surfaces were formed within the 45-32 Ma episode:

I. The Xanthi detachment extending over more than $100 \mathrm{~km}$, from $\mathrm{E}^{\prime}$ of Kavala toward the NE into Bulgaria 
(Fig. 1), separates the Sidironero Complex from the uppermost ultramafic/migmatitic series of the Kimi Complex, and the Tertiary sediments. This is a moderately to the SE dipping discrete detachment surface that truncates the thrust related mylonitic foliation, lithological layering (Fig. 2), and metamorphic profile of the underlying Sidironero Complex at high angle.

II. Iasmos detachment separates the $W^{\prime}$ Kardamos Complex from the overlying Kimi Complex (Fig. 1, 2). This is, also, a discrete detachment surface that shallowly dips to the $\mathrm{W}$ truncating at intermediate to high angle the mylonitic foliation, lithological layering and the metamorphic zonation of the underlying Kardamos Complex. Both the Xanthi and the Kardamos detachment surfaces are underlain by a $\sim 0.5-4 \mathrm{~m}$ thick zone of extensive cataclasis that affected the respective underlying series.

III. Kardamos detachment separates the E' part of the Kardamos Complex from the Kimi Complex (Fig. 1,2). This NE-SW trending discrete tectonic contact is oriented subparallel to the mylonitic foliation of the underlying $\mathrm{E}^{\prime}$ Kardamos Complex. Mylonites immediately beneath the detachment surface accumulated strain through cooling as it is indicated by fracturing and cataclasis of feldspar and by strongly elongated quartz ribbons (aspect ratios $>1: 10$ ). The translation directions on the detachment surface follow the shear senses of the underlying mylonites.

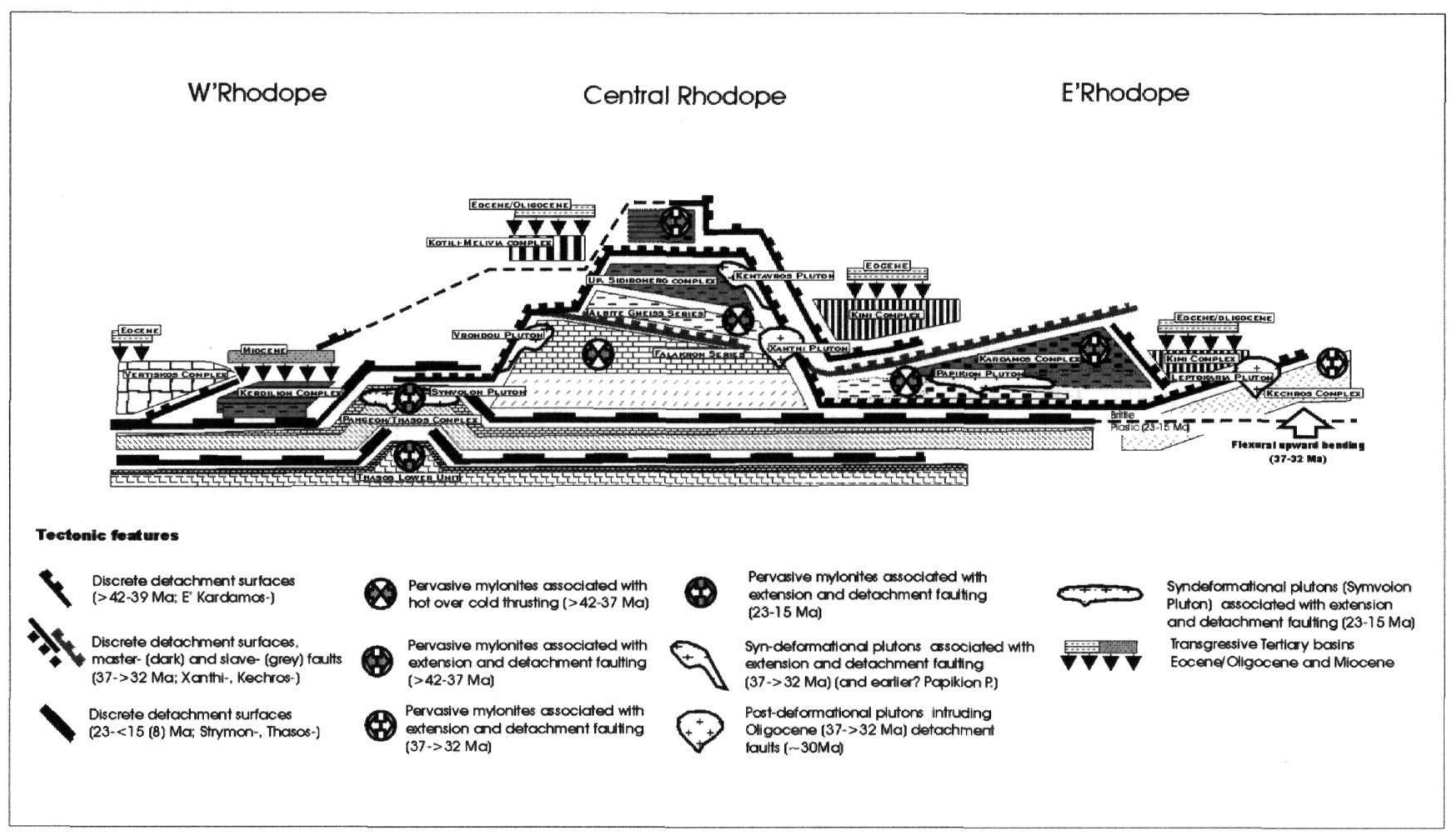

Figure 3. Schematic structural relationships among different tectonic metamorphic complexes and basins, and the geometry of various generations of extensional detachment systems, see Figs 3 for explanation of the unit fillings.

IV. Kechros detachment separates the Kechros Complex from the overlying Kimi Complex (Fig. 1, 2). This detachment broadly follows the trend of the lower greenschist facies localized shear zones. Microfabrics suggest that deformation continuing through cooling.

All these systems are associated with emplacement of the Sidironero, Kerdilion, Kardamos, and Kechros Complexes representing the footwall complexes. The hanging wall complexes of these detachment systems is composed of the E' CRZ as well as of the ultramafic/migmatitic UHP-HP series of the Kimi, Kotili-Melivia and Vertiskos Complexes. Frequent granitoids bounded to the detachment contacts suggest magmatism associated with detachment formation.

\section{AGE OF PERVASIVE STRAIN AND DISCRETE TECTONIC CONTACTS}

In the high grade upper Sidironero Complex, the age of HT metamorphism and crystallization of muscovites from the anatectic melt is constrained by U-Pb zircon SHRIMP data from migmatites (Liati and Gebauer, 1999) and by $\mathrm{Rb}-\mathrm{Sr}$ data of muscovites from pegmatoids yielding c. 40-41 Ma. Rb-Sr ages of muscovite and $\mathrm{K}-\mathrm{Ar}$ ages of hornblende from orthogneiss and amphibolite mylonites ranging at 37-41 Ma are interpreted as a minimum 
age for mylonitisation after migmatization. In the low grade lower Sidironero Complex, K-Ar ages of hornblende from amphibolite mylonites yielding c. $45 \mathrm{Ma}$ are interpreted as dating mylonitization continuing through cooling below the suggested closure temperatures of the K-Ar hornblende system. According to Dinter (1998), this downward increase of K-Ar hornblende ages resulted from earlier cooling of the lower part of the Sidronero Complex due to thrusting on top of a cold plate. The abrupt decrease in hornblende ages toward the higher Sidironero Complex suggests that thrusting continued after closure of these isotope systems along discrete zones. In the upper (E') Kardamos Complex, K-Ar data of muscovite and biotite of c. 41-c. 39 Ma constrain shearing continuing through cooling below $350-300^{\circ} \mathrm{C}$. In the Kechros complex Rb-Sr and Ar-Ar white mica dates from orthogneisses ranging between 35-39 Ma (Wawrzenitz and Mposkos, 1997; Lips et al., 2000) are roughly similar to the K-Ar hornblende ages of the upper Sidironero Complex and might be interpreted as an approximate age of mylonitization (cf. discussion in Wawrzenitz and Mposkos, 1997).

Also, intrusion ages of granitoids provide age constraints for the deformation: Near Xanthi, a mostly undeformed granodiorite intrusion into the Sidironero Complex and the Xanthi detachment surface (Fig. 1) shows K-Ar hornblende and biotite ages of 30 and $28 \mathrm{Ma}$, respectively. These suggest a minimum age of detachment formation. Inferred intrusion depth correspond to $\sim 2.5-3 \mathrm{kbar}$ being $\sim 10 \mathrm{~km}$ (Liati, 1986). A strongly deformed granodiorite intrusion into the Sidironero Complex (near Kedavros; Fig. 1) shows K-Ar hornblende ages of c. $38 \mathrm{Ma}$ (Liati, 1986) indicating a maximum age of the Xanthi detachment surface. Hornblende geothermobarometry (cf. Schmidt, 1992) estimates an intrusion depth of 5.1-5.4 kbar ( 18-19 km). Rb-Sr biotite ages from an undeformed granodiorite intrusion into the Kechros detachment surface $\left(\mathrm{N}^{\prime}\right.$ Alexandroupoli, $\mathrm{E}^{\prime}$ Rhodope; Fig. 1,2) indicate a minimum age of detachment formation of 30-32 Ma (Del Moro et al., 1988) in this area. This detachment formation was broadly simultaneously with formation of marine basins in the E' Rhodope.

\section{MIOCENE CORE COMPLEX FORMATION (WESTERN RHODOPE)}

The Thasos/Pangeon complex (W' Rhodope, Fig. 1) is characterized by flat laying pervasive shear zones showing predominant top to the SW, and locally, top to the NE sense of shear. Deformation continued during cooling. On Thasos Island, $\mathrm{Rb}-\mathrm{Sr}$ data of white mica and biotite downwardly decrease to 20-18 Ma and 15-12 Ma, respectively (Fig. 1), in accordance with progressive extensional exhumation of an increasingly deeper crustal part within the Early Miocene (Wawrzenitz and Krohe, 1998). K-Ar and Rb-Sr mica ages and fission track ages of the sheared metamorphic rocks constrain formation of discrete low angle normal (Strymon- and Thasos-) detachment surfaces bounding the Thasos/Pangeon complex between c. 15 Ma, and >8 Ma (Fig. 1; Dinter, 1995; Wawrzenitz and Krohe, 1998). This temporally coincides with formation of Miocene basins in the W' Rhodope (Fig. 1) interpreted as supradetachment basins (Dinter et al., 1995).

\section{DISCUSSION}

\section{Syn- and Post thrusting detachment faults (<42-30 Ma interval)}

Summing up, Sidironero, Kardamos and Kechros Complexes experienced strong pervasive deformation at $\mathrm{T} \approx 500^{\circ} 700^{\circ} \mathrm{C}$ within the $<42-30 \mathrm{Ma}$ interval, during decompression/exhumation and cooling. Differences in thermochronological evolutions among these Complexes within the $<42-30 \mathrm{Ma}$ interval (as suggested from the geochronological data) reflect variations of mass movements paths during exhumation from different initial depths. To the top and bottom, this crustal section is bounded by extensional detachment systems formed in the $<42-30 \mathrm{Ma}$ and 23-8 Ma intervals, respectively. Thrusting within the Sidironero Complex during decompression was accompanied by continuous removal of material from top of (i.e. exhumation of) the Sidironero Complex. The main removal mechanism was normal faulting. This is evident from preservation of a metamorphic upper plate consisting of pre-Late Eocene metamorphic rocks (Kimi-Complex) and transgressive Late Eocene to Oligocene by marine ( $E^{\prime}$ Rhodope) sediments. Migmatites of the upper Sidironero Complex formed simultaneously with the Early Oligocene basins that transgressed onto the Kimi Complex. Thus, several tens of $\mathrm{km}$ of material have been excised along the contact of the Kimi and Sidironero Complex, that is within the crustal profile, which is indicative for normal faulting. According to our kinematic reconstruction juxtaposition of these two complexes occurred on two successive detachment systems:

I) We suggest a first stage of normal faulting, coeval with thrusting of hot over cold metamorphic rocks created the $E^{\prime}$ Kardamos detachment system (Fig. 3) was formed, which is associated with plastic strain.

II) A second stage of normal faulting (extension) clearly developed after compression tectonics and after the migmatitic stage within the Sidironero and Kardamos Complexes. This stage created the Xanthi detachment 
system and the E' Kardamos detachment system (E' of Xanthi-Echinos, see Fig. 2) separating the overlying Kimi Complex (including the sediments) from the Sidironero Complex and Kardamos Complex, respectively. These systems are essentially discrete, brittle surfaces, truncating the thrust related mylonites locally at high angles and caused exhumation from depths not higher than $19 \mathrm{~km}$ as this system is.

We interpret the $\mathrm{W}^{\prime}$ Kardamos detachment fault as a secondary fault rooting into the Xanthi master detachment fault (Fig. 2 and 3). Both excise the Kardamos Complex representing a piece of crust between Sidironero and Kimi Complex in a way such as shown in Fig. 3. In this interpretation the Kardamos Complex (including the older E' Kardamos detachment system), forms part of the upper plate with respect to the Xanthi master detachment. The deeper Kardamos Complex showing thrusting of hot over cold rocks is equivalent to the lower and upper Sidironero Complex (symbolized in Fig. 1 and 3 by indentation of the specific signatures).

\section{XANTHI AND KECHROS DETACHMENT SYSTEMS: LARGE SCALE EXTENSIONAL RAMP-FLAT STRUCTURE}

According to geochronological data, the Kechros detachment system (E' Rhodope) was formed between '38 and $32 \mathrm{Ma}$, i.e. coeval with formation of the Xanthi detachment surface (Central Rhodope). However, the Kechros-detachment surface is associated with plastic strain and developed at greater depth as the Xanthi detachment surface.

We consider the Kechros detachment system as east continuation of the Xanthi detachment system intersecting from the brittle upper crust into a domain deforming essentially by plastic strain of quartz from the W' to the E' Rhodope. This connected Xanthi/Kechros detachment system extends, thus, over a length of about 100 $\mathrm{km}$ showing a flat and ramp structure (Fig. 2 and 3). In our structural reconstruction in the E' Rhodope this Xanthi-Kechros connected detachment system excised hot HP rocks (upper Sidironero Complex) between Kimi Complex and Kechros Complex. According to this reconstruction in $\mathrm{E}^{\prime}$ Rhodope, this detachment system removed an about $20 \mathrm{~km}$ thick piece of crust (the estimated thickness of the Kardamos +Sidironero Complexes, including Albite Gneiss and Falakron Series) from above the Kechros Complex. This is in coincidence with the reduction of the present crustal thickness from the central to the E' Rhodope from about $50 \mathrm{~km}$ to less than 30 $\mathrm{km}$ inferred from gravimetric data (Makris, 1982).

\section{CONCLUSIONS}

The structural relationships among the different shear zones and detachment systems of the Rhodope Domain can be summarized as follow (cf. Fig. 3):

(I) In the Late Eocene/Early Oligocene two episodes of extension created two sets of normal detachment systems. The older detachment system is clearly coeval with deeper level thrusting of hot over cold HP rocks ( $\mathrm{E}^{\prime}$ Kardamos detachment system; between 42 and $39 \mathrm{Ma}$ ).

(ii) The younger Xanthi- and Kechros detachment (37-30 Ma) systems post-dates thrusting and dismembered the thrust structures. In E' Rhodope, this connected Xanthi-Kechros detachment system excised a large piece of crust and emplaced the upper plate Kimi Complex upon a structurally very lower level of the previous thrust structure (Kechros Complex). Hence, in $E^{\prime}$ Rhodope, crustal thinning, occurred already in the Oligocene on the E' dipping Xanthi-Kechros normal detachment system. This event is associated with Lutetian/ Priambonian and Oligocene basin formation, volcanic activity and calc-alcaline plutonism in E' Rhodope.

(iii) Pangeon/Thasos (metamorphic core) Complexes occupying the structurally lowermost level in $\mathrm{W}^{\prime}$ Rhodope, were exhumed between c. 23 and c. 12 (8) Ma along the Strymon and Thasos normal detachment surfaces. This extension tectonics distinctly postdated exhumation of HP rocks in the Sidironero-/Kardamos and Kechros Complexes and probably reflects early Aegean back-arc extension. This stage was associated with lithospheric heating, magmatism and plastic flow of the middle crust and probably reactivated earlier formed detachment surfaces (Fig. 1).

\section{REFERENCES}

BIGAZZI, G., DEL MORO, A., INNOCENTI, F., KYRIAKOPOULOS, K., MAUNETTI, P., PAPADOPOULOS, P., NORELLITI, P. AND MAGGANAS, A. 1989. The magmatic intrusive complex of Petrola, West Thrace: Age and geodynamic significance. Geologica Rhodopica, V.1, 290-297.

BUCHER, K. AND FREY, M. 1994. Petrogenesis of metamorphic rocks. Springer Verlag, 318 pages, Berlin, 1994.

BURG, J.P., RICOU, E., IVANOV, Z., GODFRIAUX, I., DIMOV, D., AND KLAIN, L. 1996. Syn-metamorphic 
nappe complex in the Rhodope Massif. Structure and Kinematics. Terra Nova, 8, 6-15.

DEL MORO, A., INNOCENTI, F., KYRIAKOPOULOS, K., MANNETTI, P. AND PAPADOPOULOS, P. 1988.

Tertiary granitoids from Thrace (Northern Greece): Sr isotopic and petrochemical data. N.Jb.Miner.Abh. 159/ 2, 113-135.

DINTER, D.A. 1998. Late Cenozoic extension of the Alpine collision orogen, northeastern Greece: Origin of the north Aegean basin. Bull. Geol. Soc. Am. 110 (9), 1208-1230.

DINTER, D.A., MACFARLANE, A., HAMES, W., ISACHSEN, C., BOWERING, S., AND ROYDEN, L. 1995: $\mathrm{U}-\mathrm{Pb}$ and ${ }^{40} \mathrm{Ar} /{ }^{39} \mathrm{Ar}$ geochronology of the Symvolon granodiorite: implication for the thermal and structural evolution of the Rhodope metamorphic core complex, northerern Greece. Tectonics, 14 (4), 86-908.

KILIAS, A., FALALAKIS, MOUNTRAKIS, D. 1997. Alpine tectonometamorphic history of the Serbomacedonian metamorphic rocks: Implication for the Tertiary unroofing of the Serbomacedonian-Rhodope metamorphic complexes (Macedonia, Greece), Mineral Wealth, 105, 9-27.

LIATI, A. 1986. Regional metamorphism and overprinting contact metamorphism of the Rhodope zone, near Xanthi N. Greece: Petrology, Geochemistry, Geochronology. Ph.D.thesis, Techn.Univ.Braunschweig.

LIATI, A. AND GEBAUER, D. 1999. Constraining the prograde and retrograde P-T-t path of Eocene HP rocks by SHRIMP dating of different zirkon domains: Inferred rates of heating, burial, cooling and exhumation for central Rhodope, northern Greece. Contrib. Mineral. Petrol. 135, 340-354.

LIATI, A. AND MPOSKOS, E. 1990. Evolution of the eclogites in the Rhodope zone of northern Greece. Lithos, $25,89-99$.

LIATI, A. AND SEIDEL, E. 1996. Metamorphic evolution and geochemistry of kyanite eclogites in central Rhodope, northern Greece. Contrib.Mineral.Petrol. 123: 293-307.

LIPS, A.L.W., WHITE, S.H, AND WIJBRANS, J. R. 2000. Middle-Late Alpine thermotectonic evolution of the southern Rhodope Massif, Greece. Geodinamica Acta, 13, 281-292.

MAKRIS, J. 1985. Geophysics and geodynamic implications for the evolution of the Hellenides. In Stanley, D.S. and Wezel, F.C. (eds), Geological evolution of the Mediterranean Basin. Springer Verlag, New York, p.231248.

MPOSKOS, E. 1989. High-pressure metamorphism in gneisses and pelitic schists in the East Rhodope Zone (N.Greece). Mineral. Petrol., 41, 25-39.

MPOSKOS, E., KOSTOPOULOS, D. AND KROHE, A. 2001. Ultrahigh-pressure metamorphism from the Rhodope metamorphic province, Northeastern Greece: A preliminary report on a new discovery, Terra $A b$ stracts (in press).

MPOSKOS, E. AND KROHE, A. 2000. Petrological and Structural evolution of Continental High Pressure (high$P$ ) Metamorphic Rocks in the Alpine Rhodope Domain (N-Greece). In: Panayides, I., Xenophontos, C., and Malpas, J., (eds.), Proceedings of the 3.rd International Conf. on the Geology of the Eastern Mediterranean (Nicosia, Cyprus), 221-232, 2000.

MPOSKOS, E. AND LIATI, A. 1993. Metamorphic evolution of metapelites in the high-pressure terrane of the Rhodope zone, Northern Greece. Can.Mineral., 31, 401-424.

MPOSKOS, E. AND WAWRZENITZ, N. 1995. Metapegmatites and pegmatites bracketing the time of high $P$ metamorphism in polymetamorphic rocks of the E-Rhodope, N.Greece: Petrological and geochronological constraints. Geol.Soc.Greece. Special Publications. N. 4/2, 602-608.

WAWRZENITZ, N. AND MPOSKOS, E. 1997. First evidence for Lower Cretaceous high- $P$ /high- $T$ metamorphism in the Eastern Rhodope, North Aegean Region, North-East-Greece. Eur.J.Mineral., 9, 659-664.

WAWRZENITZ, N. AND KROHE, A. 1998. Exhumation and doming of the Thasos metamorphic core complex (S. Rhodope, Greece): Structural and geochronological constraints. Tectonophysics, 285, 301-332. 